\title{
Loktanella hongkongensis sp. nov., a novel member of the $\alpha$-Proteobacteria originating from marine biofilms in Hong Kong waters
}

\author{
Stanley C. K. Lau, ${ }^{1}$ Mandy M. Y. Tsoi, ${ }^{1}$ Xiancui Li, ${ }^{1}$ loulia Plakhotnikova, ${ }^{1}$ \\ Madeline $\mathrm{Wu},{ }^{1}$ Po-Keung Wong ${ }^{2}$ and Pei-Yuan Qian ${ }^{1}$ \\ ${ }^{1}$ Coastal Marine Laboratory/Department of Biology, The Hong Kong University of Science and
Technology, Clear Water Bay, Kowloon, Hong Kong SAR \\ ${ }^{2}$ Department of Biology, The Chinese University of Hong Kong, Shatin, N.T., Hong Kong SAR
}

Correspondence

Pei-Yuan Qian

boqianpy@ust.hk

\begin{abstract}
A Gram-negative, non-motile, non-spore-forming, short rod-shaped bacterium
(UST950701-009P ${ }^{\top}$ ) was isolated from a marine biofilm in Hong Kong waters. Colonies are pink in colour, convex with a smooth surface and entire edge. Brown diffusible pigment is produced. Whitish colonies, with otherwise identical morphology, emerge from every culture upon ageing. The white colonies can be maintained as separate cultures (UST950701-009W) without turning pink. UST950701-009P ${ }^{\top}$ and UST950701-009W have identical 16S rRNA gene sequences and

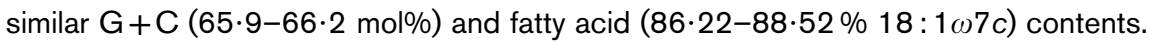

Phylogenetic analysis of the 16S rRNA gene sequence places UST950701-009P ${ }^{\top}$ within the Rhodobacter group of the $\alpha$-subclass of the Proteobacteria. The nearest neighbours belong to the genus Loktanella, with similarity values ranging from 94.5 to $95.5 \%$. Data on $G+C$ and fatty acid contents support the affiliation to the genus Loktanella. UST950701-009P ${ }^{\top}$ and $-009 \mathrm{~W}$ are heterotrophic, strictly aerobic and require $\mathrm{NaCl}$ for growth $(2 \cdot 0-14 \cdot 0 \%)$. Both grow in $\mathrm{pH} 5 \cdot 0-10 \cdot 0$ and at $8-44^{\circ} \mathrm{C}$. Both are positive in oxidase, catalase and $\beta$-galactosidase tests, but they differ in the pattern of carbohydrate oxidation and assimilation. Molecular evidence together with phenotypic characteristics shows that UST950701-009P ${ }^{\top}$ constitutes a novel species within the genus Loktanella. The name Loktanella hongkongensis sp. nov. is proposed; the type strain is UST950701-009P $\mathrm{P}^{\top}\left(=\mathrm{NRRL} \mathrm{B}-41039^{\top}=\mathrm{JCM} 12479^{\top}\right)$ and a morphovar is UST950701-009W (=NRRL B-41040 =JCM 12480).
\end{abstract}

The $\alpha$-subclass of the Proteobacteria comprises one of the largest fractions of heterotrophic bacteria in the marine environment (Cottrell \& Kirchman, 2000; Hagström et al., 2002). Among the three major groups of $\alpha$-Proteobacteria (the SAR11, SAR116 and Roseobacter clades), only the Roseobacter clade contains culturable members. Amongst the 13 recognized genera of the Roseobacter clade, Loktanella Van Trappen et al. 2004 is the most recently established. Loktanella already has three described species, Loktanella fryxellensis, Loktanella vestfoldensis and Loktanella salsilacus (Van Trappen et al., 2004); all have been recovered from

Published online ahead of print on 9 July 2004 as DOI 10.1099/ ijs.0.63294-0.

The GenBank/EMBL/DDBJ accession numbers for the 16S rRNA gene sequences of strains UST950701-009P' and UST950701009W are AY600300 and AY600301.

An expanded phylogenetic tree, scanning electron micrographs and details of sequencing primers and API test results are available as supplementary material in IJSEM Online. microbial mats in Antarctic lakes. In this study, we propose a novel species of Loktanella originating from a marine biofilm in subtropical water.

During the characterization of bacteria isolated from a 7-day-old marine biofilm in Hong Kong waters, strain UST950701-009P ${ }^{\mathrm{T}}$ was isolated on marine agar 2216 (Difco) at $30{ }^{\circ} \mathrm{C}$. UST $950701-009 \mathrm{P}^{\mathrm{T}}$ grows as pink, convex colonies with an entire margin and a smooth and shiny surface. Unless otherwise specified, all characteristics described hereafter were based on cultures grown on marine agar 2216 for $48 \mathrm{~h}$ at $30^{\circ} \mathrm{C}$. Brown diffusible pigment is produced under all culture conditions. Whitish colonies, with otherwise identical colony morphological characteristics, emerge from every culture upon ageing (3 days or beyond). The whitish colonies can be maintained as separate cultures without returning to the pink colour and are therefore regarded as a morphovar (UST950701-009W) of UST950701-009P $\mathrm{P}^{\mathrm{T}}$.

The nearly complete $16 \mathrm{~S}$ rRNA gene sequences of 


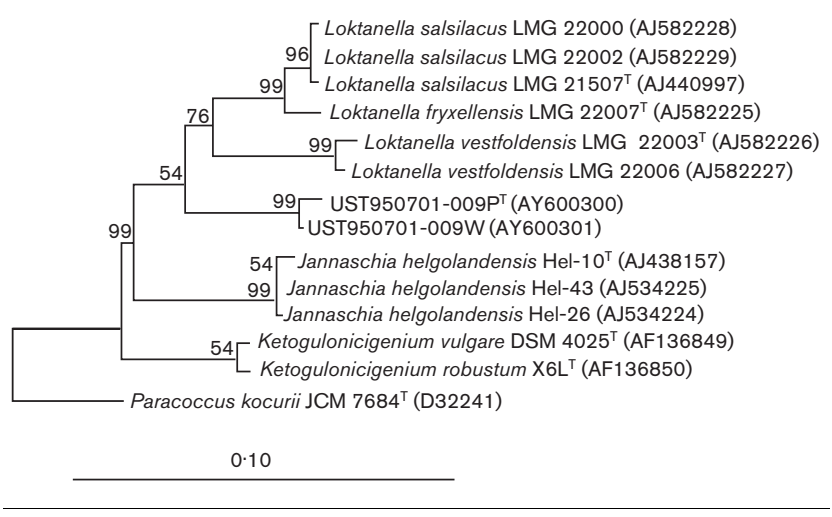

Fig. 1. Neighbour-joining dendrogram showing the estimated phylogenetic relationships among UST950701-009P', UST950701-009W and related genera in the $\alpha$-Proteobacteria on the basis of $16 \mathrm{~S}$ rRNA gene sequences. Paracoccus kocurii JCM $7684^{\top}$ was chosen as the outgroup. Bar, 1 nucleotide substitution per 10 nucleotides. Bootstrap values $>50 \%$ (500 replicates) are indicated at nodes. GenBank accession numbers are shown in parentheses. Refer to Supplementary Fig. A for a fuller tree.

UST950701-009P $\mathrm{P}^{\mathrm{T}}$ and -009W (1407 and $1336 \mathrm{bp}$, respectively) were resolved on a capillary genetic analyser (Megabace) using a dye terminator method (Rosenblum et al., 1997). Primers used in the sequencing reactions are detailed in Supplementary Table A available in IJSEM Online. Fragments of DNA sequences obtained from individual primers with replications $(n=3)$ were assembled using the Sequencher software package (Gene Codes). Sequence alignment using the bl2seq function at the NCBI server indicated full identity in the 1333 overlapping nucleotide positions of the UST950701-009P $\mathrm{P}^{\mathrm{T}}$ and $-009 \mathrm{~W} 16 \mathrm{~S}$ rRNA gene sequences with the exception of an ambiguous nucleotide position in UST950701-009W. A phylogenetic tree (Fig. 1; see also Supplementary Fig. A for a fuller tree) was constructed using neighbour-joining in the ARB software package (Ludwig et al., 2004). The stability of grouping was estimated by the bootstrap analysis ( 500 replications). The closest relatives of UST950701-009P $\mathrm{P}^{\mathrm{T}}$ were L. vestfoldensis (95.5\%), L. salsilacus (95.0\%) and L. fryxellensis (94.5\%). A tree based on maximum-parsimony method showed the same topology (data not shown).

The DNA G+C contents of strains UST950701-009P ${ }^{\mathrm{T}}$ and $-009 \mathrm{~W}$ as determined by the HPLC method described in Mesbah et al. (1989) were respectively $65 \cdot 9 \pm 0 \cdot 4$ and $66 \cdot 2 \pm 0 \cdot 4 \mathrm{~mol} \%$. These values are within the range of the DNA G $+\mathrm{C}$ contents described for the genus Loktanella (Van Trappen et al., 2004). UST950701-009P ${ }^{\mathrm{T}}$ and $-009 \mathrm{~W}$ showed highly similar cellular fatty acid profiles, as determined using the Sherlock Microbial Identification Systems according to the manufacturer's protocols (Table 1). $18: 1 \omega 7 c$ is the predominant fatty acid in both strains, comprising $84 \cdot 5-87 \cdot 0 \%$ of the total fatty acid, which is congruent with the characteristics of the genus Loktanella. On the other hand, the presence of 12:0 3-OH and the absence of summed features 2 and 7 distinguish the two strains from the already described members of the genus Loktanella (Table 1).

Table 1. Fatty acid composition of UST950701-009P' ${ }^{\top}$ UST950701-009W and the three previously described species of the genus Loktanella

Species/strains: 1, UST950701-009P ${ }^{\mathrm{T}}$; 2, UST950701-009W; 3, L. salsilacus; 4, L. fryxellensis; 5, L. vestfoldensis. Numbers given are average percentages of total fatty acids \pm range of values $(n=2)$. - , Not detectable; tr, trace amounts $(<1 \%$ of total). Unknown fatty acids are indicated by their equivalent chain length relative to the chain lengths of known straight-chain saturated fatty acids. Data for reference species are from Van Trappen et al. (2004).

\begin{tabular}{|c|c|c|c|c|c|}
\hline Fatty acid & 1 & 2 & 3 & 4 & 5 \\
\hline $12: 13-\mathrm{OH}$ & $\operatorname{tr}$ & $\operatorname{tr}$ & - & - & $5 \cdot 6 \pm 1 \cdot 4$ \\
\hline $14: 0$ & - & $\operatorname{tr}$ & - & - & - \\
\hline $16: 0$ & $5 \cdot 8 \pm 2 \cdot 1$ & $4 \cdot 6 \pm 4 \cdot 6$ & $2 \cdot 9 \pm 0 \cdot 9$ & $2 \cdot 7 \pm 1 \cdot 1$ & $2 \cdot 9 \pm 0 \cdot 7$ \\
\hline $18: 1 \omega 7 c$ & $84 \cdot 5 \pm 2 \cdot 5$ & $87 \cdot 0 \pm 2 \cdot 1$ & $87 \cdot 7 \pm 1 \cdot 9$ & $84 \cdot 9 \pm 3 \cdot 7$ & $74 \cdot 1 \pm 3 \cdot 1$ \\
\hline $18: 1 \omega 7 c$ 11-methyl & $\operatorname{tr}$ & $1 \cdot 1 \pm 1 \cdot 2$ & $\operatorname{tr}$ & - & $1 \cdot 9 \pm 0 \cdot 8$ \\
\hline Summed feature $2^{*}$ & - & - & $\operatorname{tr}$ & $1 \cdot 7 \pm 0 \cdot 7$ & - \\
\hline Summed feature 3 & $\operatorname{tr}$ & $\operatorname{tr}$ & $2 \cdot 8 \pm 0 \cdot 9$ & - & - \\
\hline Summed feature 7 & - & - & $1 \cdot 2 \pm 1 \cdot 0$ & $4 \cdot 7 \pm 2 \cdot 0$ & $4 \cdot 7 \pm 0 \cdot 7$ \\
\hline
\end{tabular}

${ }^{*}$ Summed features represent the following combinations of fatty acids: 2, 12:0 aldehyde, 16:1 iso I, 14:0 3-OH and/or unknown 10.928; 3, $16: 1 \omega 7 c$ and/or 15 iso $2-\mathrm{OH} ; 7,19: 1 \omega 6 c, 19: 0$ cyclo $\omega 10 c$ and/or unknown $18 \cdot 846$. 
The phenotypic characteristics of UST950701-009P $\mathrm{P}^{\mathrm{T}}$ and $-009 \mathrm{~W}$ are given in the species description. Anaerobic growth was examined in the Oxoid anaerobic system. Cell morphology was examined using a scanning electron microscope according to procedures in Neu et al. (2001) (Supplementary Fig. B). Cell motility and reaction to Gram stain were determined using light microscopy at $\times 1000$ according to Smibert \& Krieg (1994). Susceptibility to antibiotics was tested according to Acar (1980). The production of bacteriochlorophyll $a$ was examined according to Lafay et al. (1995). Casein hydrolysis and catalase and oxidase activities were tested according to Smibert \& Krieg (1994). The hydrolysis of Tween 80 was tested according to Baumann \& Baumann (1988). Tests for indole, acetoin and $\mathrm{H}_{2} \mathrm{~S}$ production, citrate utilization and $\beta$-galactosidase, arginine dihydrolase, lysine decarboxylase, ornithine decarboxylase, urease, tryptophan deaminase and gelatinase activities were performed using the API 20E system (bioMérieux) according to the manufacturer's instructions. The metabolism of 49 different carbohydrates was tested using both the API $20 \mathrm{E}$ and API 50CH systems according to the manufacturer's instructions.

Strains UST950701-009P $\mathrm{P}^{\mathrm{T}}$ and $-009 \mathrm{~W}$, which have identical $16 \mathrm{~S}$ rRNA gene sequences and highly similar phenotypic characteristics, can only be distinguished by colony colour, the metabolism of carbohydrates (detailed in Supplementary Table B) and the presence/absence of trace amounts of the fatty acid 14:0 (Table 1). The two strains differ from the three already described species of Loktanella by their fatty acid profiles (Table 1) and a number of physiological characteristics (Table 2). Based on tests using the API 20NE and API 20E systems, Van Trappen et al. (2004) reported that the three already described members of Loktanella did not metabolize any of the carbohydrates included in the tests. We

Table 2. Differentiation of UST950701-009P ${ }^{\top}$ and $-009 \mathrm{~W}$ from the three previously described members of Loktanella

Species/strains: 1, UST950701-009P $\mathrm{P}^{\mathrm{T}}$; 2, UST950701-009W; 3, L. salsilacus; 4, L. fryxellensis; 5, L. vestfoldensis. Data for reference species are from Van Trappen et al. (2004). +, Positive; (+), weakly positive; -, negative; ND, not described; $v$, variable.

\begin{tabular}{|lcccccc|}
\hline Characteristic & $\mathbf{1}$ & $\mathbf{2}$ & $\mathbf{3}$ & $\mathbf{4}$ & $\mathbf{5}$ \\
\hline Colony colour & \multicolumn{7}{c}{ Pink } & White & Beige Pink-beige Pink \\
Pigment & Brown & Brown & ND & ND & ND \\
Conditions for growth: & & & & & \\
$\quad$ NaCl (\%) & $2-14$ & $2-14$ & $0-10$ & $0-5$ & $0-10$ \\
Temperature $\left({ }^{\circ} \mathrm{C}\right)$ & $8-44$ & $8-44$ & $5-30$ & $5-25$ & $5-37$ \\
Nutrient agar & - & - & - & - & $(+)$ \\
Trypticase soy agar & - & - & - & - & $(+)$ \\
Hydrolysis of Tween 80 & - & - & + & + & + \\
Carbohydrate metabolism & $\mathrm{v}^{a}$ & $\mathrm{v}^{a}$ & $-{ }^{b}$ & $-{ }^{b}$ & $-{ }^{b}$ \\
& & & & & \\
\hline
\end{tabular}

${ }^{*}$ Results based on API $20 \mathrm{E}$ and API $50 \mathrm{CH}$ tests $(a)$ or API $20 \mathrm{E}$ and API 20NE tests $(b)$. observed essentially the same negative result in our API $20 \mathrm{E}$ tests (see Supplementary Table B). However, strains UST950701-009P ${ }^{\mathrm{T}}$ and $-009 \mathrm{~W}$ appeared to be able to metabolize a wide range of carbohydrates in the API $50 \mathrm{CH}$ tests, including some of those that gave negative results in the API 20E tests such as L-arabinose, D-glucose and Dmelibiose. Given the variability of results using different methods, the carbohydrate metabolism of the three already described members of Loktanella and the two strains in the present study is ambiguous.

\section{Description of Loktanella hongkongensis sp. nov.}

Loktanella hongkongensis (hong.kong.en'sis. N.L. fem. adj. hongkongensis referring to Hong Kong, the isolation source of the type strain).

Cells of the type strain are Gram-negative, short rods, immotile and not forming spores. Colonies are pink in colour, convex with entire margins and have smooth and shiny surfaces. The colony size is $1-2 \mathrm{~mm}$ after $48 \mathrm{~h}$ of cultivation on marine agar 2216 at $30^{\circ} \mathrm{C}$. White colonies, with morphological characteristics otherwise identical to those of UST950701-009P $\mathrm{P}^{\mathrm{T}}$, emerge from every culture of UST 950701-009P ${ }^{\mathrm{T}}$ after 3 days. The whitish colonies can be maintained as separate cultures without returning to the pink colour and are therefore regarded as a morphovar (UST950701-009W) of UST950701-009P $\mathrm{P}^{\mathrm{T}}$. The remaining characteristics refer to the type strain. Growth is strictly aerobic and occurs at $8-44{ }^{\circ} \mathrm{C}$ (but not at 4 or $48{ }^{\circ} \mathrm{C}$ ) and at $\mathrm{pH} 5 \cdot 0-10$. Requires $\mathrm{NaCl}$ for growth and can grow on marine agar 2216 supplemented with $\mathrm{NaCl}$ up to $14 \%$ final concentration. Cannot grow on nutrient agar or trypticase soy agar (both from Oxoid). The DNA G $+\mathrm{C}$ content is $65.9 \mathrm{~mol} \%$ and the dominant fatty acid is $18: 1 \omega 7 c(84.5 \%$ of total). Susceptible to streptomycin $(50 \mu \mathrm{g})$, penicillin $(0 \cdot 1 \mu \mathrm{g})$, chloramphenicol $(0 \cdot 5 \mu \mathrm{g})$, ampicillin $(0 \cdot 1 \mu \mathrm{g})$ and tetracycline $(0 \cdot 1 \mu \mathrm{g})$ but not kanamycin (tested up to $100 \mu \mathrm{g})$. Bacteriochlorophyll $a$, indole, acetoin and $\mathrm{H}_{2} \mathrm{~S}$ are not produced. Catalase, oxidase and $\beta$-galactosidase activities are positive, whereas arginine dihydrolase, lysine decarboxylase, ornithine decarboxylase, urease, tryptophan deaminase and gelatinase are negative. Casein and Tween 80 are not hydrolysed. Citrate is not utilized. A wide range of carbohydrates are metabolized (acid production and/ or assimilation) such as arabinose, fructose, glucose, mannitol, sucrose and xylose (see Supplementary Table B for details).

The type strain is UST950701-009P ${ }^{\mathrm{T}}\left(=\mathrm{NRRL} \mathrm{B}-41039^{\mathrm{T}}\right.$ $=\mathrm{JCM} 12479^{\mathrm{T}}$ ), which was isolated from a marine biofilm in Hong Kong waters. A morphovar of UST $950701-009 \mathrm{P}^{\mathrm{T}}$ is UST950701-009W ( $=$ NRRL B-41040 = JCM 12480).

\section{Acknowledgements}

This work was supported by a Central Allocation Grant of Hong Kong Research Grant Council (CA00/01.Sc01) to P.-Y.Q. 


\section{References}

Acar, J. F. (1980). The disc susceptibility test. In Antibiotics in Laboratory Medicine, pp. 24-54. Edited by V. Lorian. Baltimore: Williams \& Wilkins.

Baumann, P. \& Baumann, L. (1988). The marine gram-negative eubacteria: genera Photobacterium, Beneckea, Alteromonas, Pseudomonas and Alcaligenes. In The Prokaryotes, vol. 1, pp. 1302-1331. Edited by M. P. Starr, H. Stolp, H. G. Trüper, A. Balows \& H. Schlegel. Berlin: Springer.

Cottrell, M. T. \& Kirchman, D. L. (2000). Community composition of marine bacterioplankton determined by $16 \mathrm{~S}$ rRNA gene clone libraries and fluorescence in situ hybridization. Appl Environ Microbiol 66, 5116-5122.

Hagström, A., Pommier, T., Rohwer, F., Simu, K., Stolte, W., Svensson, D. \& Zweifel, U. L. (2002). Use of 16 S ribosomal DNA for delineation of marine bacterioplankton species. Appl Environ Microbiol 68, 3628-3633.

Lafay, B., Ruimy, R., Rausch de Traubenberg, C., Breittmayer, V., Gauthier, M. J. \& Christen, R. (1995). Roseobacter algicola sp. nov., a new marine bacterium isolated from the phycosphere of the toxinproducing dinoflagellate Prorocentrum lima. Int J Syst Bacteriol 45, 290-296.
Ludwig, W., Strunk, O., Westram, R. \& 29 other authors (2004). ARB: a software environment for sequence data. Nucleic Acids Res 32, 1363-1371.

Mesbah, M., Premachandran, U. \& Whitman, W. B. (1989). Precise measurement of the $\mathrm{G}+\mathrm{C}$ content of deoxyribonucleic acid by highperformance liquid chromatography. Int J Syst Bacteriol 39, 159-167.

Neu, B., Voigt, A., Mitlohner, R. \& 7 other authors (2001). Biological cells as templates for hollow microcapsules. J Microencapsul 18, 385-395.

Rosenblum, B. B., Lee, L. G., Spurgeon, S. L., Khan, S. H., Menchen, S. M., Heiner, C. R. \& Chen, S. M. (1997). New dye-labeled terminators for improved DNA sequencing patterns. Nucleic Acids Res 25, 4500-4504.

Smibert, R. M. \& Krieg, N. R. (1994). Phenotypic characteristics. In Methods for General and Molecular Biology, pp. 607-654. Edited by P. Gerhardt, R. G. E. Murray, W. A. Wood \& N. R. Krieg. Washington, DC: American Society for Microbiology.

Van Trappen, S., Mergaert, J. \& Swings, J. (2004). Loktanella salsilacus gen. nov., sp. nov., Loktanella fryxellensis sp. nov. and Loktanella vestfoldensis sp. nov., new members of the Roseobacter group, isolated from microbial mats in Antarctic lakes. Int J Syst Evol Microbiol 54, 1263-1269. 